\title{
Conceptual Metaphor Analysis of Donald Trump's Recognition of Jerusalem in Al Jazeera's News Articles
}

\section{Analisis Metafora Konseptual Pengakuan Donald Trump atas Yerusalem dalam Artikel Berita Al-Jazeera}

\author{
Fibrie Permata Sari, Bambang Yudi Cahyono*, Aulia Apriana \\ Universitas Negeri Malang, Jl. Semarang No. 5 Malang, Jawa Timur, Indonesia \\ *Penulis korespondensi, Surel: bambang.yudi.fs@um.ac.id
}

Paper received: 04-02-2021; revised: 16-02-2021; accepted: 28-02-2021

\begin{abstract}
This study investigates the conceptual metaphor of Donald Trump's recognition of Jerusalem as the capital of Israel in Al-Jazeera's news articles which were published online through its website. To achieve the objective of this study, the researcher referred to the general notion of metaphor and Lakoff and Johnson's Conceptual Metaphor Theory (CMT). Using a descriptive qualitative approach, the researcher obtained 10 news articles reporting about the topic. However, 6 articles were randomly picked to be examined further. Two stages of Charteris-Black's method (2004) namely Identification and Interpretation were adopted to examine the data. MIP were employed in the Identification stage to determine which lexical units were metaphorical. The results show that there are 4 conceptual metaphors which represent the US recognition of Jerusalem as the capital of Israel. From the results of the present study, it can be concluded that Donald Trump's recognition of Jerusalem is conceptualized into different kinds of domain. Regarding the theoretical framework, it can also be concluded that both frameworks provide a foundation in understanding the application of metaphors in news articles.
\end{abstract}

Keywords: conceptual metaphor, Donald Trump's recognition of Jerusalem, Al-Jazeera, news articles

\begin{abstract}
Abstrak
Penelitian ini bertujuan untuk menyelidiki metafora konseptual tentang pengakuan Donald Trump atas kota Yerusalem sebagai ibu kota Israel pada artikel berita yang dipublikasikan oleh situs web Al-Jazeera. Beberapa teori seperti teori umum metafora dan Conceptual Metaphor Theory (CMT) dijadikan sebagai acuan untuk mencapai tujuan penelitian. Dengan menggunakan pendekatan deskriptif kualitatif, 10 artikel berita dengan topik terkait kemudian dikumpulkan sebagai data. Enam artikel berita diambil secara acak untuk dianalisis lebih dalam. Dua tahap analisis, yaitu Identification dan Interpretation dari Metode Charteris-Black (2004), dipakai untuk menganalisis data penelitian. Pada tahap Identification, prosedur MIP digunakan untuk menganalisis unit leksikal mana yang termasuk metaforik. Hasil penelitian menunjukkan bahwa ada 4 konseptual metafora yang merepresentasikan pengakuan Donald Trump atas Yerusalem sebagai ibukota dari Israel. Berdasarkan hasil penelitian, dapat disimpulkan bahwa pengakuan Donald Trump atas Yerusalem dikonseptualisasikan ke dalam domain yang berbeda-beda. Mengenai hubungannya dengan kerangka teori, teori umum metafora dan Conceptual Metaphor Theory keduanya memberikan landasan dalam memahami aplikasi metafora dalam artikel berita.
\end{abstract}

Kata kunci: metafora konseptual, pengakuan Donald Trump atas Yerusalem, Al-Jazeera, artikel berita

\section{Introduction}

Metaphor has been regarded as part of poetic devices in literary language. Eaglestone (2002) explained that metaphor defamiliarizes language in order to be appealing to the readers. According to Ungerer and Schmid (2006), metaphor, in general, has been ordinarily 
understood based on the notion of 'similarity' or 'comparison' between the literal and the figurative meaning of an expression. More specifically, according to Leech (1969), metaphor is implicitly formed as ' $\mathrm{X}$ (tenor) is like $\mathrm{Y}$ (vehicle) in respect of $\mathrm{Z}$ (ground)'. In the example of 'Life is a walking shadow', the tenor, which is being discussed, is 'life', the vehicle is 'a walking shadow' - that is the representation of the tenor, meanwhile the ground is the sense of similarity that we achieved between the tenor and vehicle.

However, Lakoff and Johnson (2003), stated that metaphor is commonly used in everyday language. This is not only applied in language but also in our thought and action, The way we think and act is fundamentally metaphorical. Metaphor provides people with a framework to comprehend abstract concepts, such as time, life, and theory. Moreover, Kennedy (2000) stated that metaphor is usually used as a persuasive device. It is stated that public opinions are often influenced by the use of metaphor in the media without realizing what idea is surrounding it. Thus, it can be concluded that metaphor has a critical role in shaping people's viewpoint.

Furthermore, the existence of a news report plays an essential role in our society. A lot of our knowledge and perspectives of a subject comes from the news reporting published by the newspaper. According to van Dijk (1991), most people's knowledge about political or social issues derives from what we read or what we see daily. News in the press and on television are considered to be engaged by so many people around the world. The easy access to the media is also the reason why such a thing happens. Hence, the transfer of information about a particular object will not take a long time to be received.

Metaphors have been used extensively in mass media to represent a particular event. Previous studies have been investigating the metaphor usage in a business column of a particular news media (e.g., Prana, 2016), while other studies (e.g., Alawiyah, 2016) examines the types of metaphor in Indonesian and English football match report articles. Both Prana (2016) and Alawiyah (2016) referred to Lakoff and Johnson's Conceptual Metaphor Theory as the theoretical framework. Other metaphor studies in news aim at revealing the conceptual metaphor and its underlying ideology of a certain political event (Sabbah, 2010; Burnes, 2011; Jing-Schmidt \& Peng, 2017; Fallah \& Moini, 2016).

Sabbah (2010) discovered how 'war' is understood through the use of conceptual metaphor in The New York Times and The Daily Star. The result of this study concludes that even though the two newspapers are reporting the same events, there are some differences in conceptualizing the politically conflicting parties in this war throughout the pre-war, war, and post-war period. Burnes (2011) investigated the differences and similarities of metaphor used in French and British newspaper reports of 2008 parliamentary elections in Pakistan and the United States. It is found that the reports of Pakistan and America's parliamentary elections are framed in a completely distinctive way in both newspapers taken as the data. Jing-Schmidt and Peng (2017) examined the metaphor used by the Chinese Communist Party in framing the anticorruption campaign in People's Daily using Conceptual Metaphor Theory as the basic theory. Another study conducted by Fallah and Moini (2016) also investigated the use of metaphor in mass media. Their study identified how the Arab Uprisings are metaphorically represented in Persian newspaper named Keyhan and American newspaper named The Washington Post. Using Critical Metaphor Analysis proposed by Charteris-Black (2004) as the theoretical framework, this study tried to uncover any ideology embedded in the text. 
Most of the previous studies above are aimed to examine the differences and similarities of conceptual metaphors in two different newspapers or discourses. The studies that have been done by Alawiyah (2016), Prana (2016), Sabbah (2010), Burnes (2011), Jing-Schmidt and Peng (2017) are aimed to find out the conceptual metaphors used in only one newspaper, two different newspapers, or even more than two discourse in framing one current affair.

The present study, however, sets out to explore the conceptual metaphor of Donald Trump's recognition of Jerusalem as the capital of Israel found in the selected articles published in Al-Jazeera online website. Donald Trump (2017 - incumbent) has officially declared the recognition of Jerusalem as the capital city of Israel on December 6, 2017. This has been reported by the media in various ways since the decision is considered as a controversy by the vast majority of world leaders. Furthermore, Al-Jazeera is chosen as the source data of analysis due to its worldwide availability and large potential of audiences. The topic of President Trump's announcement of recognizing Jerusalem as the capital city of Israel is selected over the fact that an analysis of conceptual metaphor about this specific topic has not been addressed before.

In this study, Conceptual Metaphor Theory offers an appropriate theoretical framework for the identification and interpretation of metaphors that represent Donald Trump's recognition. Lakoff and Johnson (2003) argued that metaphor is pervasive in the language we use every day, in our action, as well as in our thought. They further stated that the essential point of conceptual metaphor is understanding one thing in terms of another. For example, we often think of time in terms of money, life in terms of a journey, and etc.

Conceptual metaphor can be understood briefly as; CONCEPTUAL DOMAIN A (target) IS CONCEPTUAL DOMAIN B (source). The words in uppercase letters are the keywords that are defined in the glossary. A conceptual metaphor consists of two domains in which one domain is understood in terms of another (Kövecses, 2010). He also believes that in order to understand the relationship between domain $A$ and domain $B$, there is a set of correspondences called mappings that we need to understand. For example, the conceptual metaphor LOVE IS A JOURNEY is derived from a set of mappings that explain the concept of love in terms of a journey. These mappings can be understood after grouping the metaphorical linguistic expressions found in the text.

\section{Method}

This study uses a descriptive qualitative method. It focuses on analyzing the metaphors used in the selected news articles. Merriam (2009) stated that qualitative research focuses on process, understanding, and meaning rather than how much and how many. Thus, the product of qualitative research is highly descriptive rather than numerical oriented. Furthermore, according to Jankowski and Wester (1991), descriptive writing is one of the forms of qualitative research report. It should contain descriptive material which is the essential point of conducting qualitative research.

The data were collected through several steps as follows. Firstly, the researcher visited the Al Jazeera website and tracked for the articles by typing 'Donald Trump Jerusalem Capital City' as the keywords into the search bar. This was done to find the articles which match the topic taken as the object of this study. The results were then filtered by 'news' and ordered by 'relevance'. By doing so, the articles included in the 'news' category and the oldest articles published in December 2017 were displayed first. Thirdly, the articles with a relevant title were 
identified. After that, the researcher selected the relevant-title articles which were published in December 2017. As a result, a total of 10 articles were found. The next step was thoroughly reading all articles that had been found on the website and manually extracting them into the researcher's data collection. Lastly, the researcher analyzed the metaphorical linguistic expressions found within the extracted data. Six news articles from the researcher's data collection were randomly picked to be examined further.

To analyze the collected articles, a method proposed by Charteris-Black (2004) was applied in this study. This method consists of three stages of analysis. However, the third stage, that is explanation, was excluded because this study does not investigate the social agency involved in the production of the metaphor. The first stage is identification, in which Metaphor Identification Procedure (MIP) based on Pragglejaz Group (2007) was employed. It enabled the researcher to identify which lexical unit was metaphorical and which one was not. The researcher identified the lexical units using Cambridge Advanced Learner's Dictionary 4th Edition (CALD) and Oxford Advanced Learner's Dictionary 8th Edition (OALD).

At the second stage, that is interpretation, the researcher grouped the metaphorical linguistic expressions according to their source domain. This stage was done to form the conceptual metaphor. The detailed procedure of this stage is explained as follows. First of all, the researcher chose a target domain for this study. In this case, 'The Recognition' abbreviated as (TR) was chosen as the target domain. After that, the researcher gathered the metaphorical linguistic expressions that have a similar idea to draw a conceptual metaphor using the set of mappings listed in Lakoff and Johnson (2003), Charteris-Black (2004) and Kövecses (2010) as the reference.

\section{Findings and Discussion}

This section is started by presenting the conceptual metaphor found within the selected data as well as the frequency of occurrence of each conceptual metaphor in Table 1 below.

Tabel 1. The frequency of occurrence of each conceptual metaphor

\begin{tabular}{clcc}
\hline No & Conceptual Metaphor & Frequency & Percentage \\
\hline 1 & TR IS AN ADVERSARY & 20 & $47 \%$ \\
2 & TR IS THE CAUSE OF HEAT (FIRE) & 10 & $23 \%$ \\
3 & TR A CONFLICT & 9 & $21 \%$ \\
4 & TR IS A GAME & 4 & $9 \%$ \\
\hline & Total & 43 & $100 \%$ \\
\hline
\end{tabular}

As shown in table 1, TR IS AN ADVERSARY is the most frequent conceptual metaphor found in the collected Al-Jazeera news articles constituting $47 \%$ of the entire identified metaphors in this data. This metaphor occurs as many as 20 times within the analyzed articles. On the other hand, the least frequent conceptual metaphor is TR IS A GAME constituting $9 \%$ of the whole identified conceptual metaphor. It occurs 4 times in the analyzed data. TR IS THE CAUSE OF HEAT (FIRE) appeared as many as 10 times out of the entire data and constituted $23 \%$, while TR IS A CONFLICT appeared 9 times and constituted $21 \%$ out of the entire data.

\section{1. "TR IS AN ADVERSARY" Conceptual Metaphor}

This identified conceptual metaphor is the most frequently used metaphor in the selected articles of Al-Jazeera which cover the news of President Donald Trump's decision on 
declaring Jerusalem as the capital city. It appears 20 times, and constitutes $47 \%$ of the entire selected news articles.

\subsubsection{Identification of "TR IS AN ADVERSARY"}

In this stage, the selected data are examined based on the contextual meaning and basic meaning. The following table shows 8 metaphorical linguistic expressions of 20 expressions which represent conceptual metaphor TR IS AN ADVERSARY. These data are selected to be elaborated further after being sorted out to avoid displaying the same data twice.

Table 2. Metaphorical linguistic expressions of TR IS AN ADVERSARY

\begin{tabular}{|c|c|c|}
\hline No. & Article & Metaphorical Linguistic Expression \\
\hline 1. & 2 & Trump's decision has touched the nerve of the Arab people \\
\hline 2. & 2 & $\begin{array}{l}\text { It [US move] has certainly unified the ordinary Arab and Muslim } \\
\text { citizens to demand their government to take a much more determined } \\
\text { action to help the Palestinian cause and get away from the US }\end{array}$ \\
\hline 3. & 2 & Trump's Jerusalem decision is spoiling Christmas in Bethlehem \\
\hline 4. & 3 & $\begin{array}{l}\text { US recognition of Jerusalem as the capital of Israel ... threaten to push } \\
\text { the region into instability }\end{array}$ \\
\hline 5. & 3 & $\begin{array}{l}\text { The American recognition of Jerusalem as the capital of Israel destroys } \\
\text { the peace process }\end{array}$ \\
\hline 6. & 4 & $\begin{array}{l}\text { The announcement is likely to dash hopes that the US would give equal } \\
\text { weight to Palestinian concerns in future negotiations }\end{array}$ \\
\hline 7. & 5 & it would throw this region into "a ring of fire". \\
\hline 8. & 6 & $\begin{array}{l}\text { the decision had effectively "killed" the Israeli-Palestinian peace } \\
\text { process. }\end{array}$ \\
\hline
\end{tabular}

The underlined words above show that they are metaphorical. The basic meaning listed in the dictionary is found to be contradicted with the contextual meaning in the text and can be understood in terms of a comparison.

In datum 1, the idiomatic expression 'touched the nerve' contextually means that Trump's decision on recognizing Jerusalem as the capital city of Israel has evoked an emotional reaction, such as anger or disappointment amongst the Arab people. Meanwhile, the basic meaning of the word 'touch' as defined in CALD is to put somebody's hand onto something or someone. Given this explanation, the researcher can understand the action of evoking an emotional reaction like anger or disappointment in terms of physically touching something that potentially causes harm or damage.

In datum 2, 'unified' refers to the capability of the United States to move after Donald Trump announced that Jerusalem is the capital city of Israel. The word 'unify' according to CALD is to combine or bring something together. Meanwhile, the phrasal verb 'get away from' means to leave the US. According to CALD, this phrasal verb is defined as to escape from a place that is often difficult to do. We can understand the recognition of Jerusalem as the capital of Israel as being a person who caused a particular demand and get away from that person himself for he has caused a struggle for someone else.

In datum 3, the word 'spoil' indicates that the decision had changed the situation in Bethlehem. As for the basic meaning, the verb 'spoil' means to destroy or reduce the pleasure, interest or beauty of something. From the contextual meaning and the basic meaning, the action of changing a pleasant situation into something bad can be understood in terms of 
physically destroying something. This allows the readers to make sense of the recognition of Jerusalem in human activity terms.

In datum 4, the phrase 'threaten to push' indicates the power of US recognition of Jerusalem. Meanwhile, for the basic meaning, the verb 'threaten' is defined in CALD as to tell someone that you will kill or hurt them or cause problems for them if they do not want to do what you want. Having the power to cause instability and disadvantageous effects over a region can be understood in terms of physically harming something.

In datum 5, the verb 'destroy' indicates the disadvantageous action of the recognition taken by the United States. Meanwhile, for the basic meaning, the word 'destroy' is defined in OALD as to damage something so badly that it no longer exists or works. The disadvantageous action of Donald Trump's decision on the peace process can be understood in terms of physically damaging something.

In datum 6, the idiomatic expression 'dash hopes' indicates the possible result of the US announcement. Whereas for the basic meaning, 'dash somebody's hope' is defined as to destroy someone's hope by making what they were hoping for impossible. The verb 'dash' alone is defined as to hit something with great force, especially to cause harm or damage. The possible action that can lead to disappointment can be understood in terms of physically hitting something forcefully.

In datum 7, the verb 'throw' indicates the power of the recognition announced by Donald Trump. The phrase 'ring of fire' here indicates destruction or instability of the region affected by the announcement. As for the basic meaning, the verb 'throw' is defined as to send something from your hand through the air by moving your hand quickly. 'A ring of fire' itself refers to the path along the Pacific Ocean which is characterized by active volcanoes and earthquakes. The possibly destructive power caused by the recognition can be understood in terms of physically throwing something into something else. The concept of destruction in this expression can also be understood in terms of natural phenomena that may cause disaster.

In datum 8, the contextual meaning of the word 'killed' indicates that the decision on recognizing Jerusalem as the capital city of Israel had ended the peace process between Israel and Palestine. As for the basic meaning, the verb 'killed' is defined as causing someone or something to die. The action of ending the peace process can be understood in terms of physically causing someone to die.

\subsubsection{Interpretation of TR IS AN ADVERSARY}

From the data that have been analysed above, the recognition of Jerusalem as the capital city of Israel can be interpreted by a conceptual metaphor TR IS AN ADVERSARY. The evidence of TR IS AN ADVERSARY can be seen from the choice of words of the articles. They use phrases and words such as touch the nerve, unified, get away from, spoiling, destroy, kill and throw something into a ring of fire to describe the event in the online news media.

Lakoff and Johnson (2003) stated that there is a type of metaphors where the object is further specified as being a person. This allows the audiences to comprehend a wide variety of experiences with nonhuman entities in terms of human characteristics and activities. Kövecses (2010) also stated that personification is common in literature, but it is also pervasive in everyday discourse. Furthermore, in each of the data that have been analysed in the previous 
section, the researcher is seeing the recognition of Jerusalem as the capital of Israel, something that is nonhuman, is specified as being a human. The target domain (TR) is given the qualities of human beings such as touching, spoiling, destroying, killing as well as throwing.

However, Lakoff and Johnson (2003) stated further that each personification depends on the aspect of the person that is being picked out. As in this case, TR is personified but the metaphor is not merely TR IS A PERSON. Conceptual metaphor TR IS AN ADVERSARY is much more specific because it provides a more specific way of thinking about the recognition of Jerusalem as the capital of Israel. This metaphor provides a thought of TR as an adversary who can destroy, hurt and even kill something else. Through the use of ADVERSARY metaphor, the recognition of Jerusalem is conceptualised as an enemy.

\section{2. “TR IS THE CAUSE OF HEAT (FIRE)” Conceptual Metaphor}

The conceptual metaphor TR IS THE CAUSE OF HEAT (FIRE) emerged 10 times within the analyzed data, and constituting $23 \%$ out of the entire analyzed news articles.

\subsubsection{Identification of "TR IS THE CAUSE OF HEAT (FIRE)"}

There are 4 diverse metaphorical linguistic expressions which represent TR IS THE CAUSE OF HEAT (FIRE) within the data after being sorted out to avoid displaying the same data twice. Those metaphorical expressions are displayed in Table 3 below.

Table 3. Metaphorical linguistic expressions of TR IS THE CAUSE HEAT (FIRE)

\begin{tabular}{lll}
\hline No. & Article & Metaphorical Linguistic Expression \\
\hline 1. & 1 & $\begin{array}{l}\text { However, if Trump decides to declare Jerusalem as Israel's capital, ... } \\
\text { it would be certain to spark an international uproar }\end{array}$ \\
2. & 2 & $\begin{array}{l}\text { The declaration has ignited the people's feelings about Palestine and } \\
\text { Jerusalem as its symbol }\end{array}$ \\
3. & 4 & $\begin{array}{l}\text { Jerusalem has a tendency to explode when you fool around with the } \\
\text { status quo } \\
\text { Ignoring the Palestinian, Muslim, and Christian rights in Jerusalem } \\
\text { will only fuel further extremism }\end{array}$ \\
\hline
\end{tabular}

In datum 1, the word 'to spark' contextually means to cause a conflict. As it is reported in the expression above, the declaration of Jerusalem has the possibility to cause a massive scale conflict. Meanwhile, the basic meaning of the verb 'spark' according to OALD is to produce small flashes of fire or electricity. The two meanings can also be understood in terms of comparison. Causing a conflict situation can be understood in terms of producing small flashes of fire or electricity.

In datum 2, the word 'has ignited' contextually means that Donald Trump's declaration of Jerusalem has caused an angry situation about Palestine and Jerusalem. As for the basic meaning, the verb 'ignite' is defined in OALD as to make something start to burn. The action of causing an angry situation can be understood in making something to start burning.

In datum 3, the word 'to explode' indicates a chaotic situation resulting from changing the status quo. As for the basic meaning, the verb 'explode' is defined in OALD as to burst or make something burst loudly and violently as well as causing damage. These meanings can also be understood in terms of comparison. The action of causing chaos can be understood in terms of making something burst violently and causing damage. 
In datum 4, the verb 'fuel' indicates a support in further extremism. Whereas, the basic meaning of 'fuel' defined in OALD is to supply something that can be burnt to produce heat or power. The action of supporting something can be understood in terms of supplying something to produce heat or power.

\subsubsection{Interpretation of "TR IS THE CAUSE OF HEAT (FIRE)"}

From the data that have been analysed above, the recognition of Jerusalem as the capital of Israel can be interpreted by a conceptual metaphor TR IS THE CAUSE OF HEAT (FIRE). The evidence of TR IS THE CAUSE OF HEAT (FIRE) can be seen from the choice of words of the articles. They use phrases and words such as to spark, has ignited, to explode and fuel to describe the recognition that has been officially declared by Donald Trump.

The basic mapping of metaphor FIRE according to Kövecses (2010) shows that the cause of fire is the metaphorical form of the cause of the situation. Meanwhile the heat of the fire is the intensity of the situation, and the fire itself is the situation (action, event, state). Having this mapping as references, the researcher can understand that TR is the cause of the situation. The intense situation that occurred after TR was announced is the heat of the fire and the conflict caused by TR is the fire.

In the finding of this study, the intensity of the situation in this event is portrayed in FIRE metaphor. Kövecses (2010) stated that FIRE metaphor is a common source domain to understand various target domains. He further stated that the intensity of a situation is the main focus of FIRE metaphor. This is due to many of the linguistic examples of this metaphor that reflect the intensity as the main focus. Another reason is that there is a clear human experimental basis for this metaphor.

\section{3. "TR IS A CONFLICT" Conceptual Metaphor}

This identified conceptual metaphor emerged 9 times within the data, and constituted $21 \%$ out of the whole data. TR IS A CONFLICT is the second most frequent metaphor found in the data.

\subsubsection{Identification of "TR IS A CONFLICT"}

The following table displays 4 different metaphorical expressions out of 9 expressions after being sorted out to avoid displaying the same data twice.

Table 4. Metaphorical linguistic expressions of "TR IS A CONFLICT"

\begin{tabular}{|c|c|c|}
\hline No. & Article & Metaphorical Linguistic Expression \\
\hline 1. & 2 & Tens of thousands have protested against the US decision \\
\hline 2. & 2 & Breaking with years of US policy \\
\hline 3. & 4 & $\begin{array}{l}\text { Trump reversed decades of US policy in defiance of warnings from } \\
\text { around the world that the gesture risked creating further unrest in } \\
\text { the Middle East. }\end{array}$ \\
\hline 4. & 6 & $\begin{array}{l}\text { The US decision is an aggression, a declaration of war on us, on the } \\
\text { best Muslim and Christian shrines in the heart of Palestine, Jerusalem. }\end{array}$ \\
\hline
\end{tabular}

In datum 1, 'against' indicates that the recognition of Jerusalem is considered to be an opposition. Meanwhile, for the basic meaning, the word 'against' is defined as to be disagreeing 
with a plan or activity. The recognition of Jerusalem in this expression can be understood in terms of an opponent.

In datum 2, the word 'breaking' indicates that the recognition of Jerusalem is considered to be against the United States policy that has been implemented for years. As for the basic meaning, the first sense of 'break' is defined in OALD as to damage or separate something into two or more parts; as a result of force. The act of against the policy can be understood in terms of physically damaging something.

In datum 3, the verb 'reversed' indicates a change of policy. In this expression, declaring Jerusalem as the capital of Israel is seen as a change of policy. As for the basic meaning, 'reverse' is defined in CALD as to change a direction, order or position of something to its opposite. The action of changing a policy can be understood in terms of changing a direction of something to its opposite.

In datum 4, the word 'aggression' and 'war' are used to express the US decision. As for the basic meaning, 'aggression' is defined in OALD as a feeling of anger and hatred that may lead to threatening and violent behaviour. Meanwhile 'war' is defined as a situation in which two groups of people are fighting with each other. From the given explanation, the declaration on Jerusalem can be understood in terms of physical aggression and war.

\subsubsection{Interpretation of "TR IS A CONFLICT"}

From the data that have been analysed, the recognition of Jerusalem as the capital of Israel can be interpreted with the source domain of A CONFLICT. The evidence of TR IS A CONFLICT can be seen from the choice of words within the articles. They use phrases and words such as against, breaking, aggression and war to describe the event.

Charteris-Black (2004) argues that the nature of the speaker's evaluation can be determined through the conflict metaphor they used. There are two types of conflict that are usually being represented in political discourse. It is either for abstract social goals that are positively evaluated such as; freedom, rights, etc or against social phenomena that are negatively evaluated such as; poverty, injustice, etc. Moreover, these social phenomena are conceptualised as 'an enemy'.

Conflict metaphor can also be identified by viewing the semantic orientation of the metaphor keywords. Words such as struggle and battle can be associated with the notion of struggle, meanwhile words such as attack, destroy and fight against can be associated with the notion of attack (Charteris-Black, 2004). As in this study, we can find keywords such as war, aggression and against which represent the notion of struggle and attack.

Charteris-Black (2004) believes that the conceptual metaphor of CONFLICT is actually motivated by two other conceptual metaphors; they are LIFE IS A STRUGGLE FOR SURVIVAL and SOCIETY IS A PERSON. This is based on the analogy between a society and an individual as they both need to struggle to survive. Through this analogy, he believes that social issues are better understood as they are portrayed as personal struggles. Thus, it enables the audiences to identify what is valued and what is rejected. As in this study, the recognition of Jerusalem is identified as being the rejected one. 


\section{4. "TR IS A GAME" Conceptual Metaphor}

The conceptual metaphor TR IS A GAME only constituting $9 \%$ of the entire analyzed data and appeared 4 times within analyzed data. This metaphor is the least frequent amongst the identified metaphors in this study.

\subsubsection{Identification of "TR IS A GAME"}

Table 5 below shows 2 metaphorical expressions out of 4 expressions after being sorted out to avoid displaying the same data twice.

Table 5. Metaphorical linguistic expressions of "TR IS A GAME"

\begin{tabular}{lll}
\hline No. & Article & Metaphorical Linguistic Expression \\
\hline 1. & 3 & this is playing with fire \\
2. & 6 & $\begin{array}{l}\text { Saeb Erekat, the chief Palestinian negotiator, told Al Jazeera that } \\
\text { Trump had "disqualified his country from any possible role in the } \\
\text { peace process". }\end{array}$ \\
\hline
\end{tabular}

In datum 1, the idiomatic expression of 'playing with fire' means that recognizing Jerusalem as the capital city of Israel is dangerous and risky for it may cause problems. The word 'fire' here indicates the unpleasant situation. As for the basic meaning, the verb 'play' is defined in CALD as to take part in a game or other organized activity. Meanwhile, the word 'fire' is defined as the state of burning that produces flames that send out heat and light. The declaration which is considered to be dangerous can be understood in terms of playing in a competition or game.

In datum 2, the word 'disqualified' indicates an exclusion of taking part in the peace process. Meanwhile, the basic meaning of 'disqualified' according to CALD is defined as to stop someone from being in a competition because they are unsuitable or have done something wrong. The exclusion of a country from taking part in the peace process can be understood in terms of disqualification in a competition.

\subsubsection{Interpretation of "TR IS A GAME"}

From the data that have been analysed above, the recognition of Jerusalem as the capital of Israel can be interpreted with the conceptual metaphor of GAME. The evidence of conceptual metaphor TR IS A GAME can be seen from the choice of words of the articles. They use words such as play and disqualify to describe the recognition. Fallah and Moini (2016) claimed that conceptual metaphor of GAME implies that there is a political game amongst the world leaders who have power in a particular region. Semino and Masci (1996) further claimed that within sport or game metaphors, the complexities of ideological issues are simplified and politics is presented in a relatively simple domain with clear participants (the party 'teams'), goals (winning) and outcomes (victory or defeat). Fallah and Moini (2016) further claim in their study that this conceptual metaphor implies a high-level power race in a particular region and it diminishes the people. The high-level powers who participated in this race are presented as the players in a game metaphor.

\section{Conclusions}

By analysing the conceptual metaphor of the recognition of Jerusalem as the capital of Israel in selected Al Jazeera's news articles, this study has shown how Donald Trump's recognition of Jerusalem is conceptualised into different kinds of domain. This 
conceptualisation was identified through the use of the lexical units. Ever since news plays an essential role in giving information about many things, the findings of conceptual metaphor in this study has helped provide an elaboration about metaphors used in the selected news articles.

The finding of ADVERSARY metaphor is found to be correlated with CONFLICT metaphor as they both conceptualised what is considered to be disadvantageous as an enemy. Portraying the US recognition as an enemy generates a more simple way of comprehending this event. Meanwhile, through the metaphor of CAUSE OF HEAT (FIRE), the US recognition is conceptualised as the cause of the intensifying situation in Israel and Palestine. The GAME metaphor is found to be the least frequent metaphor found in this study. However, this conceptual metaphor provides an understanding of how this particular event is involved in a political game. The emphasis of players involved in this game can also be identified through the choice of words in the data. Furthermore, the contextual meaning and the basic meaning of the lexical unit plays an essential role in determining whether it is metaphorical or not. Both meanings of the lexical unit must be able to be understood in terms of comparison, otherwise it cannot be concluded as metaphorical.

In regard to the use of the theoretical framework, it can be concluded that Conceptual Metaphor Theory framework provides the foundation of understanding the application of conceptual metaphor in a discourse. The stages of Charteris-Black's methodology (2004) adopted in this study has proven to be an effective approach to analyze the data. However, a more specific and structured procedure is required in the first stage of the method (Identification). Thus, the researcher decided to employ the MIP procedure to identify which lexical unit is metaphorical. The use of this procedure has been a useful method in identifying the metaphorical expressions.

This study suggests further research studies to examine the political leaders' choices of metaphor employed in spoken discourse such as speeches or television interviews. These kinds of subjects are worth studying as they might contain a wealth of data about conceptual metaphors. Furthermore, the communicative purpose of the subject may also be revealed through the use of metaphors. This approach may help the future researchers to produce a much more critical and in-depth analysis.

\section{References}

Alawiyah, N. Z. (2016). Conceptual metaphors in English and Indonesian online news articles of football match reports. (Unpublished undergraduate thesis) Universitas Negeri Malang, Malang, Indonesia.

Burnes, S. (2011). Metaphors in press reports of elections: Obama walked on water, but Musharraf was beaten by a knockout. Journal of Pragmatics, 43, 2160-2175. doi:10.1016/j.pragma.2011.01.010

Charteris-Black, J. (2004). Corpus approaches to critical metaphor analysis. Houndmills: Palgrave Macmillan.

Eaglestone, R. (2002). Doing English: A guide for literature students. Taylor \& Francis e-library.

Fallah, N., \& Moini, M. R. (2016). A critical metaphor analysis of arab uprisings in The Washington Post and Keyhan editorials. Metaphor and the Social World, 6(1), 79-102. doi: 10.1075/msw.6.1.04fal.

Jing-Schmidt, Z. \& Peng, X. (2017). Winds and tigers: Metaphor choice in China's anti-corruption discourse. Lingua Sinica, 3(2). doi: 10.1186/s40655-016-0017-9.

Kennedy, V. (2000). Metaphors in the news-introduction. Metaphor and Symbol, 15(4), 209-211. doi: 10.1207/S15327868MS1504_2

Kövecses, Z. (2010). Metaphor: A practical introduction. New York: Oxford University Press 
Lakoff, G., \& Johnson, M. (2003). Metaphors we live by. London: The University of Chicago Press.

Leech, G. N. (1969). A linguistic guide to English poetry. London: Longman Group Ltd.

Merriam, S. B. (2009). Qualitative research: A guide to design and implementation. San Francisco: John Wiley \& Sons, Inc.

Pragglejaz Group. (2007). MIP: A method for identifying metaphorically used words in discourse. Metaphor and Symbol, 22(1), 1-39. doi: 10.1080/10926480709336752

Prana, B. G. (2016). Analysis of conceptual metaphors used in business columns in the Jakarta Post. (Unpublished undergraduate thesis). Universitas Negeri Malang, Malang, Indonesia.

Sabbah, F. (2010). Conceptual metaphors of war in news reports covering the 2003 invasion of Iraq by the New York Times and the Daily Star. Papers from the Postgraduate Conference in Linguistics \& Language Teaching, Lancaster University, Lancaster.

Semino, E., \& Masci, M. (1996). Politics is football: Metaphor in the discourse of Silvio Berlusconi in Italy. Discourse \& Society 7(2), 243-269. DOI: 0.1177/0957926596007002005

Ungerer, F., \& Schmid, H. (2006). An introduction to cognitive linguistics. Britain: Pearson Education Limited.

Van Dijk, T. A. (1991). Media contents. The interdisciplinary study of news as discourse. In Nicholas W. Jankowski and Klaus Bruhn Jensen (Ed.). A handbook of qualitative methodologies for mass communication research (108-120). New York: Routledge.

Jankwoski, N. W., \& Wester, F. (1991). History. The qualitative tradition in social science inquiry: Contribution to mass communication research. In Nicholas W. Jankowski and Klaus Bruhn Jensen (Ed.). A handbook of qualitative methodologies for mass communication research (44-74). New York: Routledge. 